\title{
Late Quaternary climatic and oceanographic changes in the Northeast Pacific as recorded by dinoflagellate cysts from Guaymas Basin, Gulf of California (Mexico)
}

\author{
Andrea M. Price, ${ }^{1}$ Kenneth N. Mertens, ${ }^{2}$ Vera Pospelova, ${ }^{1}$ Thomas F. Pedersen, ${ }^{1}$ \\ and Raja S. Ganeshram ${ }^{3}$ \\ Received 7 June 2012; revised 7 January 2013; accepted 2 February 2013; published 27 March 2013.
}

[1] A high-resolution record of organic-walled dinoflagellate cyst production in Guaymas Basin, Gulf of California (Mexico) reveals a complex paleoceanographic history over the last $\sim 40 \mathrm{ka}$. Guaymas Basin is an excellent location to perform high resolution studies of changes in late Quaternary climate and paleo-productivity because it is characterized by high primary productivity, high sedimentation rates, and low oxygen bottom waters. These factors contribute to the deposition and preservation of laminated sediments throughout large portions of the core MD02-2515. In this study, we document dinoflagellate cyst production at a centennial to millennial scale throughout the late Quaternary. Based on the cyst assemblages, three dinoflagellate cyst zones were established and roughly correspond to Marine Isotope Stages (MISs) 1 to 3. MISs 1 and 3 are dominated by cysts of heterotrophic dinoflagellates, whereas MIS 2 is characterized by enhanced variability and a greater proportion of cysts produced by autotrophic taxa. The most dominant dinoflagellate cyst taxa found throughout the core were Brigantedinium spp. and Operculodinium centrocarpum. Dansgaard-Oeschger event 8 is observed in the dinoflagellate cyst record where it is characterized by an increase in warm taxa, such as Spiniferites pachydermus. Other intervals of interest are the Younger Dryas where warmer conditions are recorded and the Holocene which is characterized by the consistent presence of tropical species Stelladinium reidii, Tuberculodinidum vancampoae, Bitectatodinium spongium, and an increase in Quinquecuspis concreta. Changes in cyst assemblages, concentrations, and species diversity, along with geochemical data reflect major orbital to millennial-scale climatic and oceanographic changes.

Citation: Price, A. M., K. N. Mertens, V. Pospelova, T. F. Pedersen, and R. S. Ganeshram (2013), Late Quaternary climatic and oceanographic changes in the Northeast Pacific as recorded by dinoflagellate cysts from Guaymas Basin, Gulf of California (Mexico), Paleoceanography, 28, 200-212, doi:10.1002/palo.20019.

\section{Introduction}

[2] Climate change occurs at various time scales, and many Quaternary paleo environmental studies have focussed on variability occurring at orbital to millennial scales [e.g., Jouzel et al., 2007; Fletcher and Sánchez Goñi, 2008], namely Marine Isotope stages (MISs) and the quasiperiodic Dansgaard-Oeschger (D-O) events. D-O events are well documented by $\delta^{18} \mathrm{O}$ records from the Greenland ice sheet

All Supporting Information may be found in the online version of this article.

${ }^{1}$ School of Earth and Ocean Sciences, University of Victoria, Victoria, British Columbia, Canada.

${ }^{2}$ Research Unit for Palaeontology, Ghent University, Gent, Belgium.

${ }^{3}$ School of Geosciences, Grant Institute, University of Edinburgh, Edinburgh, UK.

Corresponding author: A. M. Price, School of Earth and Ocean Sciences, University of Victoria, OEASB, PO A405, Box 1700 STN CSC, Victoria, BC V8W 2Y2, Canada. (pricea@uvic.ca)

(C)2013. American Geophysical Union. All Rights Reserved. 0883-8305/13/10.1002/palo.20019 [i.e., Dansgaard et al., 1993], where positive excursions mark warm interstadials and occur on average $\sim 1500$ years apart [Clement and Peterson, 2008]. During extreme cold stadials, termed Heinrich events [Broecker et al., 1992], ice-rafted debris was deposited in the North Atlantic.

[3] Millennial-scale variability is most pronounced in the North Atlantic, but is also observed in paleoclimate records from lower latitudes including the tropics [e.g., Clement and Peterson, 2008]. The apparent synchronicity and global nature of these events suggest a tight coupling between shifts in atmospheric and ocean circulation over broad areas [Behl and Kennett, 1996; Hendy and Kennett, 1999]. Regions in the northern tropics are particularly sensitive due to latitudinal shifts in the Intertropical Convergence Zone (ITCZ) and related shifts in precipitation patterns [e.g., Peterson et al., 2000]. The latitudinal position of the ITCZ is influenced by seasonal differences in temperature and incoming solar insolation, as well as El Niño-Southern Oscillation (ENSO) variability on interannual time scales. During warm episodes, the pole-to-equator gradient is lessened, shifting the ITCZ further north, while the opposite occurs during cold periods [e.g., Asmerom et al., 2010]. 
[4] Orbital-scale oscillations are also observed in the northeast Pacific (continental northwest). The climate was moderate during MIS 3 and correlates to intermediate levels of summer isolation [Grigg et al., 2001]. During MIS 2 pollen records indicate conditions were colder and drier than at present in the continental northwest [Grigg et al., 2001]. Model simulations suggest that these conditions were related to the large spatial extent of the Laurentide ice sheet causing a decrease in northern hemisphere temperatures and an overall southern displacement of the jet stream [Bartlein et al., 1998]. MIS 1 saw increased amounts of summer solar insolation [Kutzbach and Liu, 1997], and changes in vegetation from the Southwestern U.S. suggest that the early MIS 1 was generally more arid, with a seasonal shift in precipitation patterns from winter to summer precipitation [Betancourt, 1984].

[5] The Gulf of California (herein referred to as the Gulf) is an excellent location to investigate millennial-scale variability during the last glacial period because it has a monsoonal climate that is heavily modulated by the location of the ITCZ, and nearby pressure systems such as the North Pacific High (NPH) and Sonoran Desert Low (SDL) (Figure 1). Guaymas Basin, located in the central Gulf, is suggested to be an ideal recorder of paleoceanographic information because it is characterized by low oxygen bottom water, seasonal patterns in upwelling and precipitation, and high primary productivity which contribute to the frequent deposition of laminated sediments. Guaymas Basin has been the focus of late Quaternary paleoclimate reconstructions, especially over the past $\sim 17$ ka [e.g., Keigwin and Jones, 1990; Sancetta, 1995; Pride et al., 1999; Barron et al., 2004; Dean, 2006]. These studies have provided valuable information on past climatic and oceanographic conditions in the Northeast Pacific since the Last Glacial Maximum
(LGM). For example, Pride et al. [1999] studied nitrogen isotopes and biogenic silica (BioSi) records from cores JPC56 and GCC55 in Guaymas Basin and found laminated sediments with high $\delta^{15} \mathrm{~N}_{\text {org }}$ and BioSi accumulation rates during the Bølling-Allerød (B-A), while the Younger Dryas (YD) and end of the late glacial were characterized by nonlaminated sediments, low BioSi, and lower $\delta^{15} \mathrm{~N}_{\text {org }}$. They attributed these shifts to widespread changes in the extent of sub-oxic subsurface waters, variations in upwelling and mixing, and/or the latitudinal migration of the ITCZ. More recently, Barron et al. [2004] analyzed geochemical, diatom, and silicoflagellate records from DSDP Site 480 from $\sim 15$ to 1 ka. Like Pride et al. [1999], they found that the B-A was characterized by diatom rich laminated sediments, while the YD saw a decline in biogenic silica. Barron et al. [2004] also documented an increase in $\mathrm{CaCO}_{3}$ and the presence of tropical diatom species that suggest reduced upwelling conditions during the YD. In addition, DSDP sites 479-480 were investigated by Byrne et al. [1990], where they analyzed pollen and dinoflagellate cysts from MIS 10 to MIS 1.

[6] In this study, we use dinoflagellate cysts to investigate orbital to millennial scale variability in primary productivity and climate over the past $40 \mathrm{ka}$ BP. Dinoflagellates are one of the most important groups of primary producers in coastal and estuarine systems, with over 1555 known free-living marine species worldwide [Gómez, 2005]. Importantly, unlike siliceous or calcareous microfossils which are subject to dissolution, many dinoflagellate species produce an organic-walled resting cyst that is resistant to physical, chemical and biological degradation [e.g., Dale, 1996]. Dinoflagellate species have different environmental preferences and their distribution in surface sediments has been shown to correlate well with physical (i.e., salinity, temperature) and
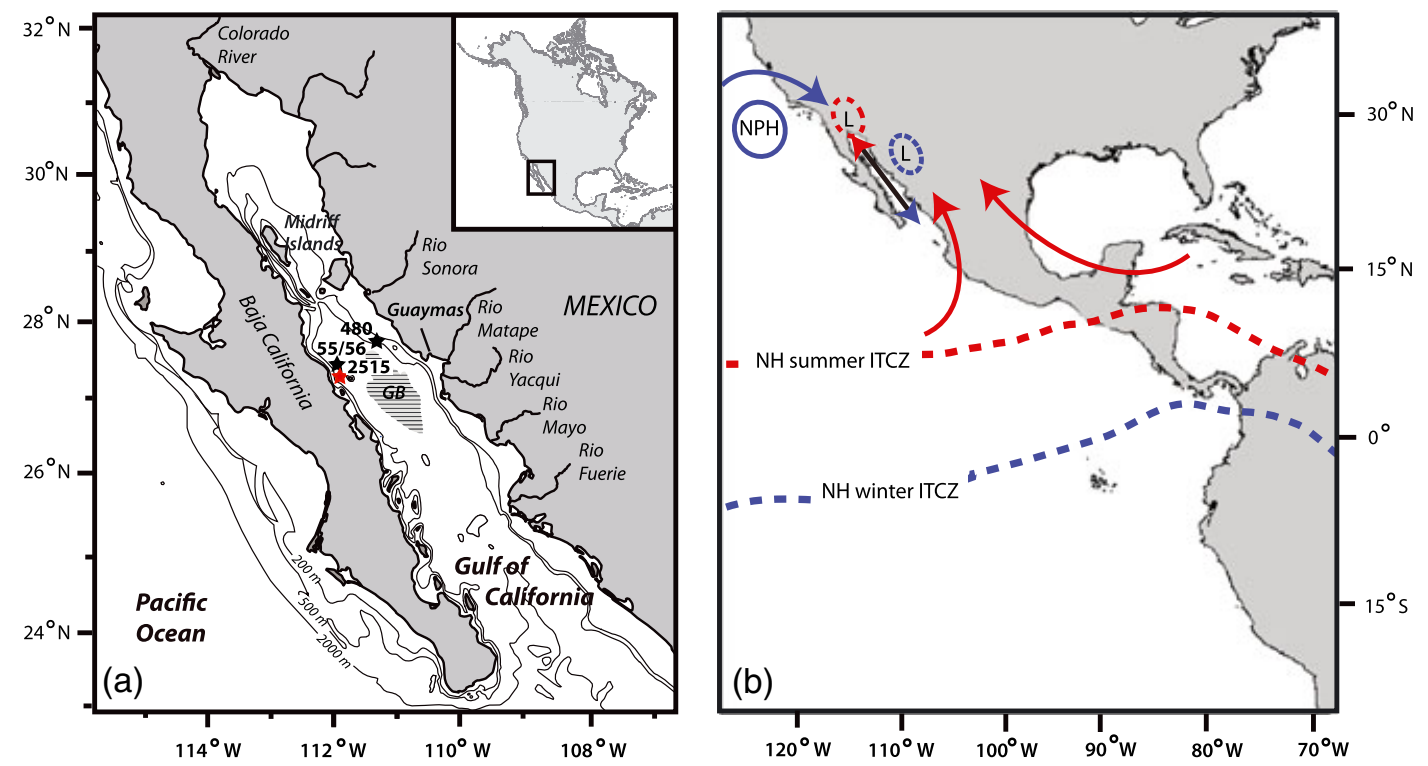

Figure 1. (a) Map of the study area showing the locations of MD02-2515 (this study) and other nearby cores, GGC-55/JPC-56 and DSDP-480. Bathymetric contours are in metres. Guaymas Basin (GB) is shown by horizontal lines. (b) The east tropical Pacific. Approximate locations of the present day Intertropical Tropical Convergence Zone (ITCZ) (dashed line), moisture sources (solid colored arrows), North Pacific High (NPH) (solid oval), Sonoran Desert Low (L) (dashed ovals), and prevalent wind direction in the Gulf (doubled-headed arrow). Features shown in red correspond to Northern Hemisphere (NH) summer locations or sources (for moisture), while features shown in blue correspond to $\mathrm{NH}$ winter locations. 
biogeochemical (i.e., nutrient levels, productivity) conditions of the upper water column [e.g., Marret and Zonneveld, 2003]. Over the last few decades, cyst assemblages have been developed as tools used in paleo environmental reconstructions. They are used to determine past sea-surface temperature (SST), sea-surface salinity (SSS), primary productivity, eutrophication, pollution, and sea-ice coverage [e.g., Matsuoka, 1999; Rochon et al., 1999; de Vernal et al., 2001; Pospelova et al., 2002; Marret and Zonneveld, 2003; Radi and de Vernal, 2004; Dale, 2009].

[7] This study analyzes dinoflagellate cyst records at the centennial to millennial scale in the Northeast Pacific over the late Quaternary. We document variations in dinoflagellate cyst species composition and abundance over the past $40 \mathrm{ka}$ in Guaymas Basin. Our objectives are (1) to describe changes in marine primary productivity in relation to past climatic variability, (2) to determine if dinoflagellate cyst assemblages record millennial-scale to orbital-scale paleoceanographic changes in the Gulf of California, (3) to compare our records to other proxies of sea-surface conditions in the Gulf, and (4) to provide further insights into the oceanographic and climatic history of the region over the late Quaternary.

\section{Environmental Setting}

\subsection{Physiography}

[8] The Gulf of California is a narrow marginal sea that opens into the subtropical Pacific Ocean. It is located between the Baja Peninsula and northwest coast of Mexico and is approximately $1000 \mathrm{~km}$ in length and $150 \mathrm{~km}$ in width, reaching water depths of over $2500 \mathrm{~m}$ (Figure 1a) [Bray, 1988a]. Guaymas Basin is situated approximately in the center of the Gulf and is an elongate semi-enclosed basin that formed via seafloor spreading [Dean, 2006]. Small rivers contribute some terrigenous material into the basin (Figure 1a), however fluvial input of terrigenous material is thought to be minor [Baba et al., 1991; Baumgartner et al., 1991; Thunell et al., 1993].

\subsection{Modern Oceanographic and Climatic Setting of the Gulf of California}

[9] The Gulf of California is the only evaporative basin adjacent to the Pacific Ocean. It is unique in that unlike many midlatitude evaporative basins, the Gulf of California has net outflow at the surface (above $250 \mathrm{~m}$ ) and inflow at depth (500-250 m) [Bray, 1988b]. Surface circulation and upwelling are controlled by atmospheric systems, where wind direction and strength determine the location and intensity of upwelling in the Gulf [Thunell et al., 1993; Thunell et al., 1994; Douglas et al., 2007].

\subsubsection{Water Masses}

[10] There are a number of water masses present in the Gulf that impact primary productivity and lamination preservation. The bottom water mass, the Pacific Deep Water (PDW), is found below depths of $\sim 1000 \mathrm{~m}$ in the Gulf. At depths between $\sim 500$ and $1000 \mathrm{~m}$, Pacific Intermediate Water (PIW) flows into the Gulf creating a persistent Oxygen Minimum Zone (OMZ). The OMZ causes slope sediments at these depths to be sufficiently depleted in oxygen that bioturbation is inhibited, allowing for the preservation of laminated sediment [Cheshire et al., 2005]. The upper $\sim 500 \mathrm{~m}$ involved in thermohaline circulation consists of three layers, with inflow at $500-250 \mathrm{~m}$, outflow at $250-50 \mathrm{~m}$, and a surface layer $(\sim 50-0 \mathrm{~m})$ that reverses seasonally with the wind direction [Bray, 1988b]. During summer, warm surface water is transported into the Gulf with southeasterly winds (Figure 1b). In winter, the opposite occurs and colder surface water is transported out of the Gulf. Water mass formation occurs in the northern Gulf where Subsurface Subequatorial Water (SSW) and water from the Colorado delta mix by winter convection, tidal mixing, and buoyancy-driven horizontal circulation, forming Northern Gulf Water (NGW) [Bray, 1988a; Pride et al., 1999]. Water mass formation in the northern Gulf contributes significantly to high productivity in Guaymas Basin [Baumgartner, 1987]. Upwelling occurs in the depth range of the Central Gulf Water (CGW, 250-50 m); thus the nutrient content of this water mass can have a substantial influence on the productivity of the Gulf [Baumgartner, 1987].

\subsubsection{Climate}

[11] The Gulf of California displays strong seasonality due to a monsoonal climate driven by atmospheric changes in circulation, in particular the locations of the ITCZ, the $\mathrm{NPH}$, and the SDL (Figure 1b). Ocean dynamics are also influenced by the seasonal locations of these weather systems [Douglas et al., 2007]. The winds associated with the NPH and SDL act to control surface circulation and mixing in the Gulf, as well as cause large evaporation rates [Pares-Sierra et al., 2003]. In the modern environment SSTs range from $\sim 14^{\circ} \mathrm{C}$ to over $30^{\circ} \mathrm{C}$ [Roden, $1958 ;$ Bray, 1988a]. The greatest seasonal fluctuation in sea-surface conditions occurs in the northern Gulf [Roden, 1958].

[12] In winter (November to March) winds are northwesterly (Figure 1b) and come from over the deserts of the American southwest. They are low in humidity acting to increase evaporation rates and are responsible for transporting large amounts of dust into the northern and central Gulf [Douglas et al., 2007]. These winterly winds also lower SST and promote mixing in the upper ocean, causing the thermocline to disappear and establishing upwelling. Upwelling begins along the eastern margin of the Gulf and may expand across the basin [Thunell, 1998], acting to fuel high primary productivity. In summer, the northwesterly winds diminish and reverse, producing weak southerly winds [Douglas et al., 2007]. The slackening of winds causes upwelling to relax and warm equatorial Pacific surface water is able to penetrate into the Gulf [Thunell, 1998]. In summer and early fall (April to October), SST exceeds $29^{\circ} \mathrm{C}$ due to increased solar insolation, diminished upwelling, and the intrusion of warm equatorial water. By the middle of summer, a thick layer $(\sim 150 \mathrm{~m})$ of warm $\left(>28^{\circ} \mathrm{C}\right)$ water covers the central and southern Gulf, creating a deep thermocline [Douglas et al., 2007]. The water column becomes highly stratified and without the supply of nutrients from depth, the surface water becomes depleted above the thermocline, and primary productivity is reduced [Thunell et al., 1996]. In addition, summer is the rainy season, with the northward location of the ITCZ. Most of the precipitation occurs from July to September [Calvert, 1966].

\section{Material and Methods}

[13] The $\sim 63.5 \mathrm{~m}$ long giant piston core MD02-2515 was collected from Guaymas Basin $\left(27^{\circ} 29.01^{\prime} \mathrm{N}, 112^{\circ} 04.46^{\prime} \mathrm{W}\right.$, $881 \mathrm{~m}$ water depth) in June 2002 during the second leg of 
the MONA cruise of the RV Marion Dufresne [Beaufort et al., 2002]. The age model used in this study was developed by Pichevin et al. [2012] and is also described by McClymont et al. [2012]. Chronology of the section of core analyzed in this study (top $48 \mathrm{~m}$ ) is based on 17 accelerator mass spectrometry (AMS) ${ }^{14} \mathrm{C}$ dates measured on bulk organic matter and two additional measurements on planktonic foraminifera [Pichevin et al., 2012]. Ages are in calibrated calendar years before present.

[14] The core is laminated for considerable portions of its length, and lamination thickness is variable [Cheshire et al., 2005]. Occasional intervals of non-laminated sediment occur, some of which were slightly to heavily bioturbated [Beaufort et al., 2002; Figure 2]. The sediments range in composition from sand to silty clay to diatom ooze (Figure 2). Sedimentation rates are very high, ranging from $\sim 22$ to $275 \mathrm{~cm} \mathrm{ka}^{-1}$ and averaging $\sim 120 \mathrm{~cm} \mathrm{ka}^{-1}$ (Figure 2).

\subsection{Palynological Sample Preparation and Microscopy}

[15] One centimeter thick sediment slices were sampled every $\sim 10-20 \mathrm{~cm}$ along the core, corresponding to a sampling resolution of $\sim 90-300$ years. Additional samples were analyzed at a higher resolution to better constrain the duration of peaks in the dinoflagellate cyst record. Each sample represents 4-45 years, averaging $\sim 8$ years of accumulation. A total of 286 sediment samples were treated using a standard palynological processing technique described in Price and Pospelova [2011], in order to recover dinoflagellate cysts and other palynomorphs (organic-walled microfossils). All palynomorphs were analyzed using a Nikon Eclipse $80 i$ light microscope at $600 \mathrm{X}$ and $1000 \mathrm{X}$ magnifications.

[16] Dinoflagellate cysts were identified according to the paleontological taxonomy system described in Lentin and Williams [1993]. A list of all dinoflagellate cyst taxa recorded in this study and their corresponding biological affinities is provided in the auxiliary material. An average of 393 cysts was counted per sample (min. 298, max. 946). Dinoflagellate cyst accumulation rates (cysts $\mathrm{cm}^{-2} \mathrm{yr}^{-1}$ ) were calculated by multiplying the cyst concentration (cysts $\mathrm{g}^{-1}$ ), by the sedimentation rate $\left(\mathrm{cm} \mathrm{yr}^{-1}\right)$, and dry bulk density $\left(\mathrm{g} \mathrm{cm}^{-3}\right)$. Dry bulk density measurements were determined by dividing the dry sediment weight $(\mathrm{g})$ by the wet volume $\left(\mathrm{cm}^{3}\right)$.

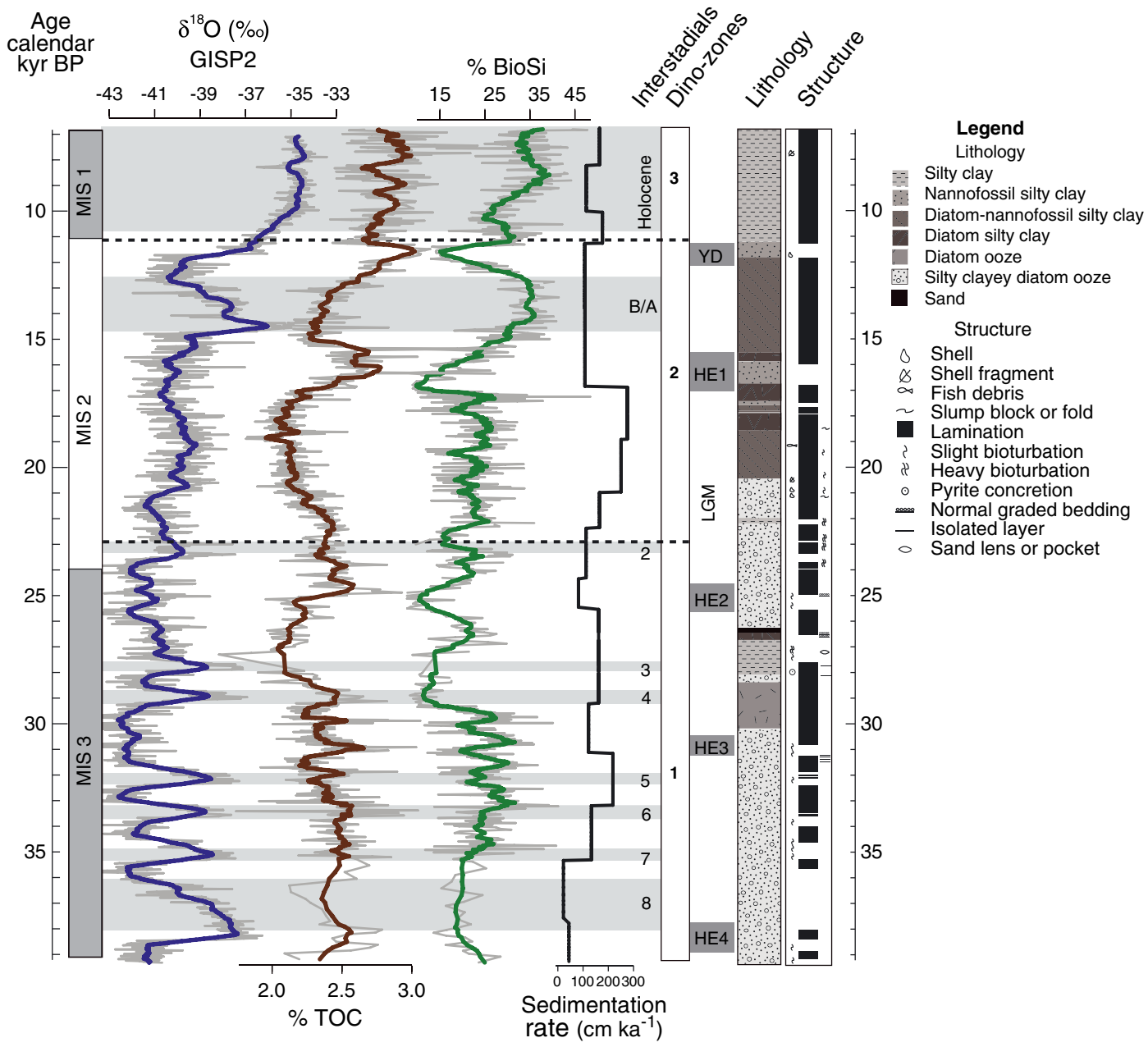

Figure 2. GISP II $\delta^{18} \mathrm{O}$ [Stuiver and Grootes; 2000], \% total organic carbon (\% TOC) [Pichevin et al., 2012], \% biogenic silica (\% BioSi) [Pichevin et al., 2012], sedimentation rate, lithology, and structure [Beaufort et al., 2002]. Bold curves are 10 point averages. Interstadials are shown by shaded horizontal bars and dinoflagellate cyst zones are separated by dashed lines. Heinrich events and the Younger Dryas are highlighted in dark grey. 


\subsection{Species Diversity and Multivariate Statistical Analyses}

[17] The Shannon-Wiener index, a diversity index, was calculated for each sample as follows:

$$
H^{\prime}=-\sum_{i=1}^{s}\left(p_{i} \ln p_{i}\right)
$$

where $H^{\prime}$ is the Shannon-Wiener index, $S$ is the total number of species (species richness), and $p_{i}$ is the relative abundance of species $i$. This diversity index is advantageous as it takes into consideration the number of species present as well as the "evenness" of the species. The more similar numerically each species is to each other the greater the evenness of the sample.

[18] Statistical analyses were performed on dinoflagellate cyst relative abundances using CANOCO 4.5 for Windows [ter Braak and Smilauer, 2002]. The data were logarithmically transformed to increase the statistical weight of species that occur in lower abundances, as these species are often characterized by a narrower ecological affinity. Detrended Correspondence Analysis (DCA) was first used to test the nature of variability within the dinoflagellate cyst assemblage.
The length of the first gradient in standard deviation units was 1.9, which indicates linear variation. Principal components analysis (PCA) was performed, which reduces the dimensionality of the data set while maintaining the variation.

\section{Results}

\subsection{Dinoflagellate Cyst Relative Abundances, Concentrations, and Accumulation Rates}

[19] Diverse, abundant, and well-preserved dinoflagellate cyst assemblages were recorded from 286 samples in the upper $48 \mathrm{~m}$ of core MD02-2515. The most dominant dinoflagellate cyst taxa found consistently throughout were Brigantedinium spp. (9-84\%). Other important contributors were Operculodinium centrocarpum sensu Wall and Dale 1966 (0-80\%), Spiniferites pachydermus (0-81\%), S. bentorii (0-54\%), Dubridinium spp. (0-43\%), Lingulodinium machaerophorum (0-33\%), Quinquecuspis concreta (0-33\%), cyst of Polykrikos cf. kofoidii (0-30\%), and Echinidinium aculeatum (0-10\%) (Figure 3).

[20] A total of 62 dinoflagellate cyst taxa were identified (auxiliary material Table S1). The number of species in each sample ranged from 13 to 33, with an average of 24 .

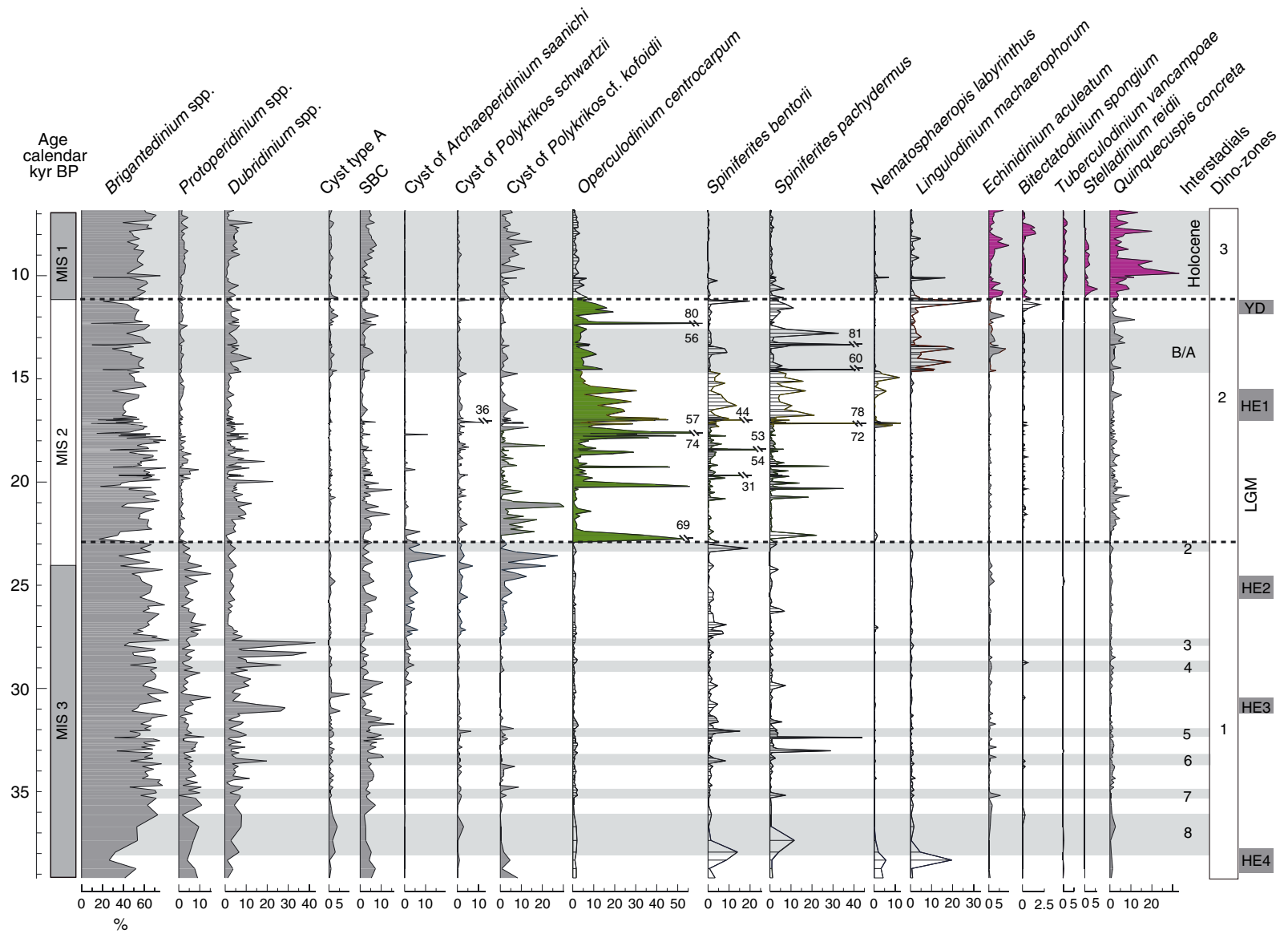

Figure 3. Relative abundances (\%) of selected dinoflagellate cyst taxa. Cysts produced by autotrophic taxa are shown in white. Cysts produced by heterotrophic taxa are shown in grey. Dinoflagellate cysts species that characterize particular zones are highlighted in color. Note that all species are shown on the same horizontal scale with the exceptions of Brigantedinium spp. $(1 / 2 \mathrm{X})$ and Bitectatodinium spongium (4X). Interstadials are shown by shaded horizontal bars and dinoflagellate cyst zones are separated by dashed lines. Heinrich events and the Younger Dryas are highlighted in dark grey. 
The Shannon-Wiener index varied from 0.84 to 2.49 , averaging 1.8. It was lowest from $\sim 36-27 \mathrm{ka}$ and highest in the Holocene and at the bottom of the core $\sim 38-39 \mathrm{ka}$ (Figure 4). Dinoflagellate cyst concentrations vary by two orders of magnitude, from $\sim 3500$ cysts $\mathrm{g}^{-1}$ to $\sim 183,000$ cysts $\mathrm{g}^{-1}$, averaging $\sim 18,500$ cysts $\mathrm{g}^{-1}$. Large fluctuations are especially apparent in sediments younger than $\sim 23 \mathrm{ka}$, particularly by cysts of autotrophic taxa (Figure 3), where one taxon increases in abundance by $\sim 30-80 \%$ from the preceding samples and subsequently declines by a similar magnitude in the following samples. In general, concentrations of heterotrophic $(\mathrm{H})$ taxa are much greater than concentrations of autotrophic (A) taxa and is reflected in the $\mathrm{H} / \mathrm{A}$ ratio (Figure 4). Dinoflagellate cyst accumulation rates have fluctuated during the late Quaternary varying from $~ 36$ to 8200 cysts $\mathrm{cm}^{-2} \mathrm{yr}^{-1}$, averaging $\sim 1600$ cysts $\mathrm{cm}^{-2} \mathrm{yr}^{-1}$. Cyst accumulation rates are highest from 22.3 to $16.9 \mathrm{ka}$, roughly corresponding to the LGM and HE1. Although only relative abundances of individual dinoflagellate cyst taxa are displayed in Figure 3, cyst concentrations and accumulation rates show similar trends.

\subsection{Statistical Analyses and Dinoflagellate Cyst Zones}

[21] Principal components analysis performed on logarithmically transformed relative abundance data yields four axes explaining $21.4 \%, 11.8 \%, 9.6 \%$, and $8.0 \%$ of the variance, respectively, for a total of $50.7 \%$. PCA provides insight into similarities and differences in the dinoflagellate cyst assemblages recorded throughout the core. Figure 5, a PCA biplot, shows the ordination of samples and species along the two most dominant ordination axes, PCA1 and PCA2. Samples and species that are more similar to each other are located nearer to each other on the diagram.

[22] Based on sample scores from PCA axes 1 and 2, and visual inspection of the dinoflagellate cyst abundances, three dinoflagellate cyst zones were established. The first zone $(40-22.8 \mathrm{ka})$ is characterized by negative PCA1 and PCA2 values, zone $2(22.8-11.1 \mathrm{ka})$ is characterized by mostly positive PCA1 and/or PCA2 values, while zone $3(11.1-6.8 \mathrm{ka})$ is distinguished by very high positive PCA2 values and mostly negative PCA1 values (Figure 4). Although all three zones are dominated by Brigantedinium spp., zone 2 is characterized by the consistent presence and often high and

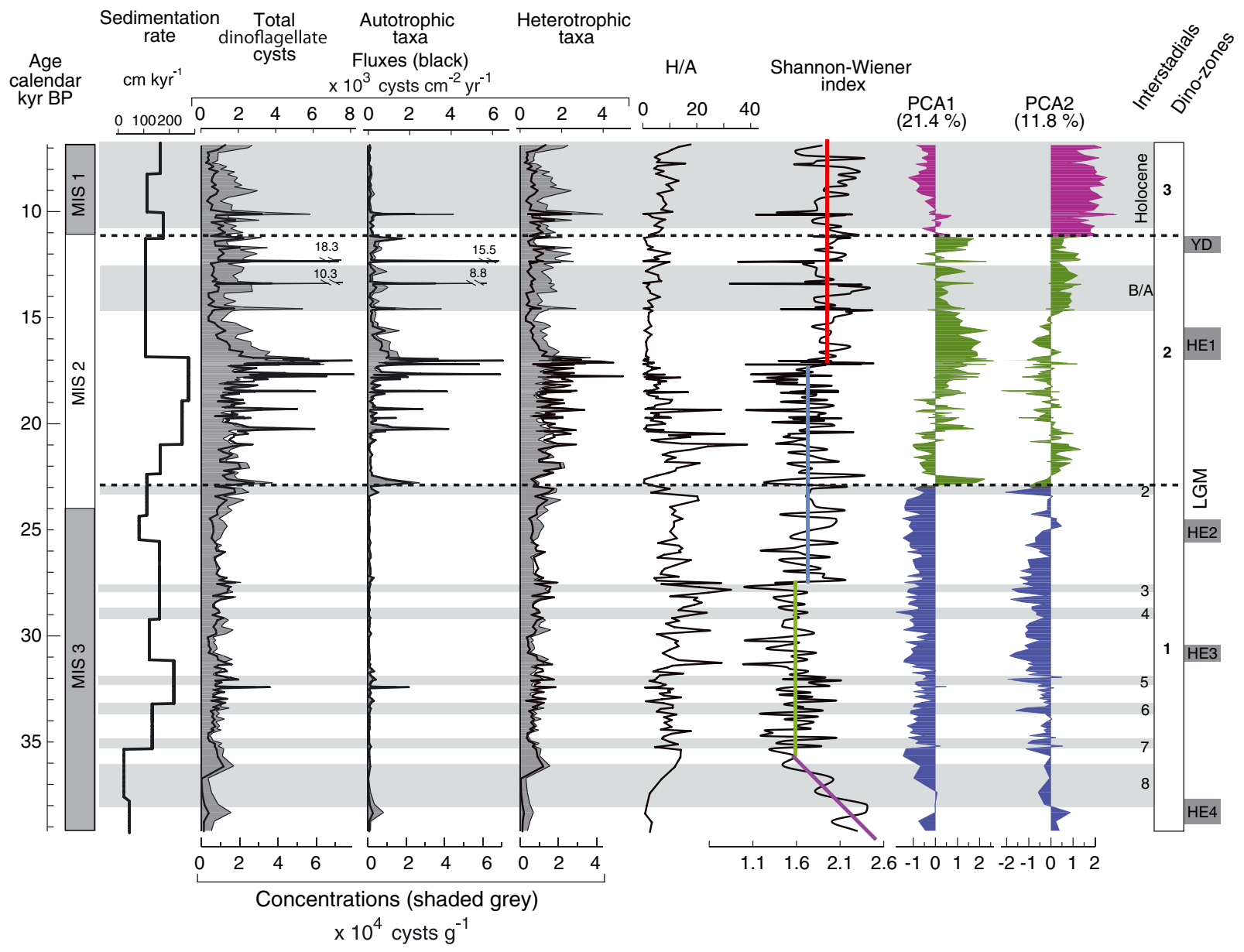

Figure 4. Sedimentation rate; concentrations and fluxes for total, autotrophic and heterotrophic taxa; ratio of heterotrophic $(\mathrm{H})$ to autotrophic $(\mathrm{A})$ taxa $(\mathrm{H} / \mathrm{A})$; Shannon-Wiener index with colored vertical lines highlighting distinct changes; and sample scores for PCA axes 1 and 2, where different colors highlight changes between zones. Interstadials are shown by shaded horizontal bars and dinoflagellate cyst zones are separated by dashed lines. Heinrich events and the Younger Dryas are highlighted in dark grey. 


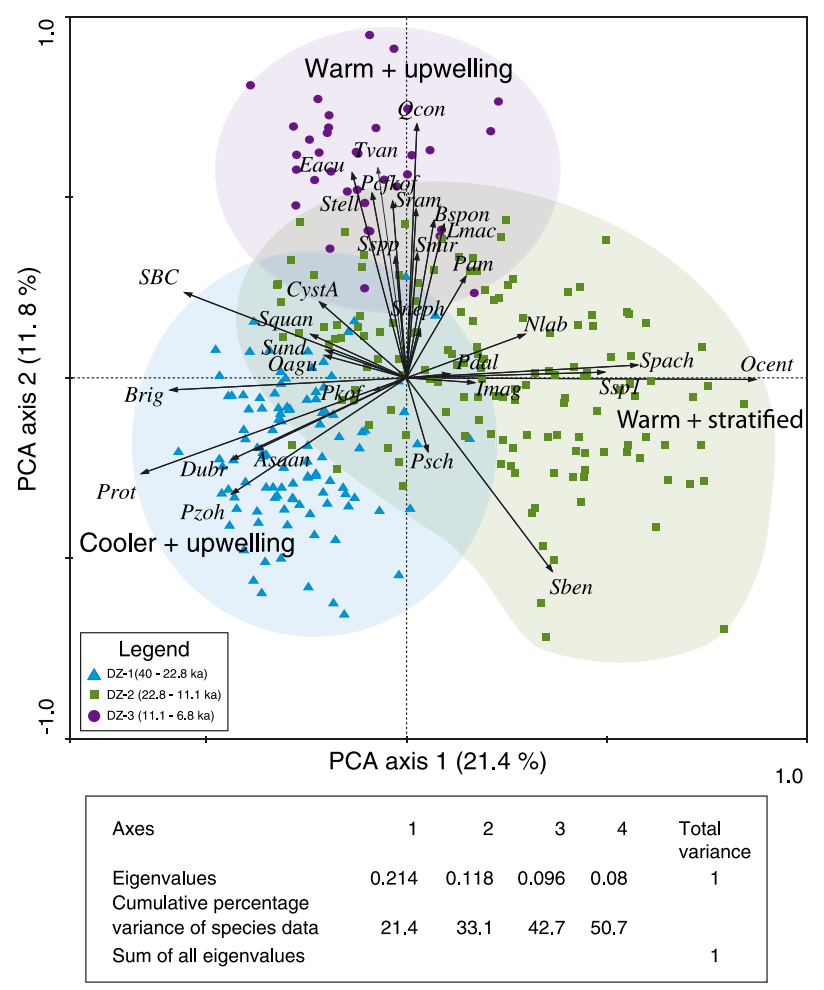

Figure 5. Ordination diagram generated by principal components analysis (PCA) showing dinoflagellate cyst taxa (black arrows) and ordination of samples (coloured dots, squares and triangles). Abbreviations for cysts of autotrophic taxa: Imap, Impagidinium spp.; Nlab, Nematosphaeropsis labyrinthus; Lmac, Lingulodinium machaerophorum; Oagu, Operculodinium aguinawense; Ocent, Operculodinium centrocarpum sensu Wall and Dale 1966; Pdal, cyst of Pentapharsodinium dalei; Pzoh, Polysphaeridium zoharyi; Sben, Spiniferites bentorii; Smir, Spiniferites mirabilis; Spac, Spiniferites pachydermus; Sram, includes Spiniferites ramosus and Spiniferites bulloideus; Ssp1, Spiniferites type 1; Sspp, Spiniferites spp.; Tvan, Tuberculodinium vancampoae. Abbreviations for cysts of heterotrophic taxa: Asaan, cyst of Archaeperidinium saanichi; Bspp, Brigantedinium spp; CystA, Cyst type A; Dubr, Dubridinium spp; Eacu, Echinidinium aculeatum; Pkof, cyst of Polykrikos kofoidii; Pcfkof, cyst of Polykrikos cf. kofoidii; Psch, cyst of Polykrikos schwartzii; Proto, Protoperidinium spp; Qcon, Quinquecuspis contreta; Sneph, Selenopemphix nephroides; Squa, includes Selenopemphix quanta and cysts of Protoperidinum nudum; Sund, Selenopemphix undulata; SBC, spiny brown cysts and Echinidinium species; Stel, Stelladinium reidii. Eigenvalues are shown at the bottom of the figure.

fluctuating values of Operculodinium centrocarpum (Figure 3) and zone 3 by the consistent presence of warm water taxa Bitectatodinium spongium, Tuberculodinium vancampoae, and Stelladinium reidii. Characteristic species of each dinoflagellate cyst zone are highlighted in color in Figure 3.

\subsection{Orbital Scale Variability: MIS 1-3}

[23] Three dinoflagellate cyst zones were established and roughly correspond to MISs $1-3$. MIS 3 is characterized by the predominance of cysts produced by heterotrophic taxa, in particular Brigantedinium spp., Protoperidinium spp., Dubridinium spp., and spiny brown cysts (Figures 3 and 4). These taxa have a global distribution but are often found in highest abundance in areas of high nutrients such as in or near active upwelling cells, areas affected by eutrophication, or well-mixed regions [e.g., Bujak, 1984; Matsuoka et al., 2003; Radi et al., 2007; Pospelova et al., 2008; Verleye and Louwye, 2010]. Absolute cyst abundances of both autotrophic and heterotrophic taxa are relatively stable during MIS 3, and with the exception of the bottom of the record (36-39 ka), the Shannon-Wiener index is low. During the latter part of MIS 3, preceding the LGM, there is an increase in cysts of Polykrikos cf. kofoidii and cysts of Archaeperidinium saanichi. In the modern Gulf of California, cysts of $P$. cf. kofoidii reach maximum abundances of $\sim 30 \%$ in the northern section (D. Wall, Dinoflagellate cysts and acritarchs from California current surface sediments, 227 pp, University of Saskatchewan, unpublished $\mathrm{PhD}$ thesis, 1986), where large seasonal changes in SST, SSS, and river discharge occur.

[24] Cyst concentrations and fluxes show the greatest variability during MIS 2 where both cysts of autotrophic and heterotrophic taxa show numerous spikes (Figure 4). MIS 2 encompasses the Last Glacial Maximum (LGM), and in addition to showing large fluctuations, dinoflagellate cyst fluxes and concentrations are higher on average (Figure 4). Elevated sedimentation rates $\left(\sim 165-275 \mathrm{~cm} \mathrm{ka}^{-1}\right)$ contribute to the high cyst fluxes during the first half of MIS 2. O. centrocarpum substantially increases, characterizing this period. It is produced by a cosmopolitan, autotrophic species able to tolerate a wide range of temperatures and salinities and is found from the tropics to the poles [Marret and Zonneveld, 2003]. S. pachydermus also increases and fluctuates greatly in MIS 2 (Figure 3), and in modern surface samples, $S$. pachydermus is predominately found in tropical and sub-tropical regions [Marret and Zonneveld, 2003].

[25] The MIS 1 encompasses the early to mid Holocene and the tropical dinoflagellate cyst species $T$. vancampoae, $S$. reidii, and $B$. spongium increase in abundance and become consistently present, albeit in low abundances (Figure 3). Numerically less abundant taxa such as these can also be very valuable paleoenvironmental indicators. These species often have a narrower ecological niche and thus relatively small changes in their abundance can indicate important changes in environmental conditions. These three species prefer warm SSTs and have highest relative abundances in subtropical to tropical regions in modern sediments [Marret and Zonneveld, 2003]. T. vancampoae can be found in brackish to full marine environments, while $B$. spongium is found in greatest abundances in high salinity surface water ranging from 34.6 to 36.7 psu [Marret and Zonneveld, 2003]. The distribution of B. spongium has also been related to regions with well-mixed surface waters near rivers, upwelling cells [Zonneveld, 1997; Zonneveld and Jurkschat, 1999], and active upwelling [Zonneveld and Brummer, 2000]. S. reidii is a subtropical species however its distribution is not well documented in modern environments [Marret and Zonneveld, 2003]. In addition, Quinquecuspis concreta and Echinidinium aculeatum reach their maximum relative abundances in the MIS 1 . Q. concreta and E. aculeatum are cysts allegedly produced by heterotrophic dinoflagellates and have been associated with increased nutrient conditions, 
such as in or near upwelling fronts [e.g., Marret and Zonneveld, 2003; Pospelova et al., 2008; Verleye and Louwye, 2010].

\subsection{Millennial-Scale Variability}

\subsubsection{Dansgaard-Oeschger Events}

[26] Of the D-O events that have occurred in the past $40 \mathrm{ka}$, event 8 appears to have had the most impact on the dinoflagellate cyst assemblages in Guaymas Basin. D-O event 8 is distinguished by an increase in cysts produced by autotrophic taxa, specifically Lingulodinium machaerophorum (a species characteristic of relaxed upwelling), Spiniferites taxa, and Nematosphaeropsis labyrinthus (Figure 3). Furthermore $\mathrm{BioSi} \%$ is relatively low (Figure 2). Around D-O events $5-7$, there is an increase in Spiniferites taxa, specifically S. pachydermus and S. bentorii (Figure 3). S. pachydermus is more prevalent in waters with warmer SSTs in the modern Gulf (Wall, unpublished $\mathrm{PhD}$ thesis, 1986) and higher abundances of Spiniferites taxa have also been suggested to reflect warmer waters in the NE Pacific [Prauss, 2002; Pospelova et al., 2006]. There is no clear change in the assemblages during D-O events 2, 3, or 4.

\subsubsection{Heinrich Events and the Younger Dryas}

[27] Four Heinrich events (HEs) occurred in the past 40 $\mathrm{ka}$, preceding some D-O events. HE1 at 17-16 ka is well documented by the dinoflagellate cyst assemblage (Figure 3), TOC \%, and BioSi \% (Figure 2). During this event total dinoflagellate cyst concentrations increase dramatically. This is due to high absolute abundances of cysts produced by autotrophic taxa, in particular by $O$. centrocarpum, S. bentorii, and S. pachydermus (Figures 3 and 4). In contrast, absolute abundances of heterotrophic taxa decline throughout HE1. Earlier HEs 2-4 are not observed in the cyst record, but HEs 2 and 3 are characterized by low BioSi $\%, \delta^{30} \mathrm{Si}$, Si:N ratios, and $\mathrm{Si}: \mathrm{C}_{\text {org }}$ ratios [Pichevin et al., 2012].

[28] The YD is also well observed in the paleoenvironmental record where it is characterized by a drop of $\sim 15-20 \%$ in $\mathrm{BioSi} \%$, a peak in the autotrophic taxon L. machaerophorum, moderate abundances of $O$. centrocarpum, and a decrease in the absolute abundance of heterotrophic taxa (Figures 2-4). In our core, the beginning of the YD is not well constrained due to limitations of the age model, but corresponds to the interval of low \% BioSi in Barron et al. [2004, 2005]. This interval of low \% BioSi coincides with the peak in L. machaerophorum, thus suggesting a shift in the dominant component of phytoplankton population from diatoms to autotrophic dinoflagellates.

\section{Discussion}

[29] Guaymas Basin is very productive in the modern environment, as documented by high diatom and biogenic silica fluxes in sediments trap samples [Thunell et al., 1994; Thunell, 1998] and by high dinoflagellate cyst concentrations in surface sediment samples [MartínezHernández and Hernández-Campos, 1991; Wall, unpublished $\mathrm{PhD}$ thesis, 1986; this study]. Over the late Quaternary there have been a number of important orbital and millennial-scale climatic events. D-O interstadials and Heinrich events in particular have impacted both productivity and oceanatmosphere circulation in the Northeast Pacific. Here we demonstrate how dinoflagellate cyst production has responded to such changes in Guaymas Basin over the late Quaternary.

[30] The distribution of dinoflagellate cysts in sediments is influenced by environmental factors such as SST, nitrate, SSS, and phosphate [e.g., Marret and Zonneveld, 2003]. Some taxa such as Brigantedinium spp. and Operculodinium centrocarpum are cosmopolitan with a global distribution, whereas other taxa have a narrower geographic distribution. SST is one of the most important factors in explaining the distribution of many dinoflagellate cysts in surface sediments [Marret and Zonneveld, 2003]. Nutrients levels and upwelling intensity are also important, especially in determining the abundance of taxa. For instance dinoflagellate cyst taxa produced by heterotrophic species such as Brigantedinium spp., cysts of Protoperidinium spp., and Dubridinium spp., are found in highest abundances in areas with high nutrient levels or upwelling zones [e.g., Bujak, 1984; Matsuoka et al., 2003; Radi et al., 2007; Pospelova et al., 2008; Verleye and Louwye, 2010].

\subsection{The (Paleo-) Productivity Signal}

[31] In the modern environment, the Gulf of California is known for high rates of primary productivity and averages $0.38 \mathrm{~g} \mathrm{C} \mathrm{m}^{-2} \mathrm{~d}^{-1}$ [Zeitzschel, 1969]. It is comparable to upwelling regions off the coast of Baja California and North Africa, placing the Gulf of California with the world's most productive oceanic regions [Zeitzschel, 1969; Douglas et al., 2007]. High primary productivity in the Gulf is also recorded in surface sediment samples, which have high BioSi \% and high dinoflagellate cyst concentrations. In the northern Gulf, dinoflagellate cyst concentrations from surface sediments range from $\sim 4500$ to $\sim 17,000$ cysts $\mathrm{g}^{-1}$ [Pospelova et al., 2008], while in La Paz (southwestern Gulf) concentrations range from $\sim 200$ to 27,000 cysts $\mathrm{g}^{-1}$ [Limoges et al., 2010; J.-F. Kielt, Distribution des assemblages palynologiques et microfaunistiques le long des côtes Ouest mexicaines, $83 \mathrm{pp}$, Université du Quebec à Montréal, Montréal, Canada, unpublished MSc thesis, 2006], and in Guaymas Basin one surface sample had a concentration of 31,000 cysts $\mathrm{g}^{-1}$ (this study). These cyst concentrations are in the same order of magnitude as other high primary productivity zones and upwelling regions (e.g., West Africa $\sim 130$ to $\sim 65,600$ cysts $\mathrm{g}^{-1}$ [Bouimetarhan et al., 2009], the Chilean continental margin $\sim 525$ to $\sim 100,750$ cysts $\mathrm{g}^{-1}$ [Verleye and Louwye, 2010], and the Northeast Pacific $\sim 100$ to 35,000 cysts $\mathrm{g}^{-1}$ [Pospelova et al., 2008]).

[32] In Guaymas Basin sediment trap studies have shown that TOC $\%$ has no seasonal signal and is not related to the flux of biogenic material [Thunell et al., 1993; Thunell, 1998], thus it is not considered to be an indicator of primary production either in the modern environment or in the past. As shown in Figure 2 there is in fact an inverse relationship between TOC \% and BioSi \% throughout the late Quaternary. This relationship has been previously noted by Dean [2006] in Guaymas Basin cores GGC55/JPC56 and is discussed in greater detail by Pichevin et al. [2012]. According to Pichevin et al. [2012], the decoupling between TOC \% and BioSi \% may be related to the preferential preservation of $\mathrm{BioSi}$ over organic compounds, whereby TOC is diluted by the BioSi fraction and the initial $\mathrm{Si}: \mathrm{N}$ and $\mathrm{Si}: \mathrm{C}$ ratios of exported diatoms. In contrast, BioSi does show a distinct seasonal signal in sediment traps [Thunell et al., 1993, 1996; 
Thunell, 1998], where it is elevated from late fall through to early spring.

[33] Total dinoflagellate cyst production and BioSi \% are not coupled in this core. Since heterotrophic dinoflagellates can feed on diatoms as prey [e.g., Jacobson and Anderson, 1986; Hansen, 1991], one might expect there to be a relationship between cysts produced by heterotrophic dinoflagellates and BioSi. These relationships are most evident when looking at measures of absolute abundances (i.e., accumulation rates) [e.g., Price and Pospelova, 2011], however opal accumulation rates are not available at this time for the core. Thus we use abundances of cysts produced by heterotrophic dinoflagellate taxa as an indicator of primary productivity.

\subsection{Dinoflagellate Cyst Preservation}

[34] Dinoflagellate cysts deposited in oxic sediments may be affected by selective degradation over time [e.g., Zonneveld et al., 2010] in regions with low sedimentation rates. Our core collected at $881 \mathrm{~m}$ water depth, currently sits in the middle of the PIW, characterized by low oxygen concentrations. Large sections of the core are laminated (Figure 2) suggesting much of the deposition occurred in anoxic conditions. In addition sedimentation rates are high averaging $\sim 120 \mathrm{~cm} \mathrm{ka}^{-1}$, and the lack of observed degradation in the walls of sensitive cysts suggests the palynomorphs have not been noticeably affected by aerobic degradation.

\subsection{Orbital-Scale Variability: MISs 1-3}

[35] The later half of MIS 3 is documented in the section of core analyzed in this study and is dominated by cysts produced by heterotrophic dinoflagellates. Heterotrophic dinoflagellates are generally most prevalent in regions with an enhanced supply of nutrients to the surface water, such as in upwelling zones [e.g., Lewis et al., 1990; Radi et al., 2007; Pospelova et al., 2008; Verleye and Louwye, 2010], therefore we suggest enhanced upwelling conditions and lower SSTs compared with MIS 1 and 2 (Figure 5).

[36] The upper section of MIS 3 immediately precedes the LGM where a regression in sea level [Siddall et al., 2003; Peltier and Fairbanks, 2006] would have narrowed the Gulf of California exposing much of the northern Gulf. As a consequence Northern Gulf water formation likely occurred further south than its modern day location. This interval is characterized by an increase in cysts of $P$. cf. kofoidii and cysts of $A$. saanichi. Cysts of $A$. saanichi are indicative of temperate SSTs [Mertens et al., 2012]. Current surface sediments in the Gulf of California show the highest abundances of cysts of $P$. cf. kofoidii in the northern section (Wall, unpublished $\mathrm{PhD}$ thesis, 1986), where the most extreme seasonal changes in SST, SSS, and river discharge occur. Thus, we attribute the increase in cysts of $P$. cf. kofoidii during late MIS 3 to either enhanced advection of Northern Gulf water into the central Gulf, or to amplified seasonal changes in SST and SSS in the central Gulf of California.

[37] A switch from relatively stable dinoflagellate cyst concentrations and fluxes to an interval where large fluctuations are evident in these records, characterizes the transition from MIS 3 to MIS 2. Samples from dinoflagellate cyst zone 2 ( MIS 2) are more dispersed on the PCA ordination diagram (Figure 5), demonstrating the greater variation in the cyst assemblages from MIS 2. Since dinoflagellates respond to their surrounding environmental conditions, the high variability in absolute abundances of dinoflagellate cysts during MIS 2 is indicative of enhanced variability in the climatic and oceanographic conditions. The dinoflagellate species assemblage also supports unstable conditions where $O$. centrocarpum, a species commonly associated with coastal waters and has been reported to increase in abundance in unstable waters at the coastal/oceanic boundary [Dale et al., 2002], and is drastically higher and more variable during this period (Figure 3). We interpret this species to be a proxy for rapidly changing conditions in Guaymas Basin, which in turn could be related to the sea-level rise around this time [e.g., Peltier and Fairbanks, 2006]. S. pachydermus also increases and fluctuates greatly during MIS 2 (Figure 3). In modern surface samples, $S$. pachydermus is predominately found in tropical and sub-tropical regions and a sediment trap study from the Arabian Sea shows the greatest fluxes of this species a few weeks after the end of the monsoon and upwelling season, concurrent with SSTs rise [Zonneveld and Brummer, 2000]. This suggests that S. pachydermus favors periods of diminished or reduced upwelling when nutrients are still available, but when surface waters become warmer. Therefore their elevated abundance and strong fluctuations during MIS 2 in the Gulf indicate abrupt, but short in duration, intervals of increased SST and reduced upwelling. This conclusion is in part supported by the SST proxy $\mathrm{U}_{37}^{\mathrm{K}}$ ' recorded from our core, which shows the greatest fluctuation in temperature $\left(\sim 17.5-24^{\circ} \mathrm{C}\right)$ during the early part of MIS 2 [McClymont et al., 2012].

[38] During the LGM, the Laurentide and Cordilleran ice sheets on North America were at their maximum extent [e.g., Clark et al., 2009], impacting atmospheric weather patterns. In the American Southwest the LGM was cooler and experienced a greater amount of winter precipitation [Smith and Street-Perrot, 1983; Van Devender et al., 1987; Asmerom et al., 2010; Wagner et al., 2010]. The midlatitude westerlies and the ITCZ were displaced equatorward [Kutzbach, 1988; Spaulding, 1991] resulting in the southern displacement of the NPH and SDL. The southerly location of the NPH in summer is expected to have resulted in stronger winds and increased summer upwelling, while in winter the $\mathrm{NPH}$ is suggested to have been too far south to have had an effect on winds in the Gulf of California, resulting in reduced winter upwelling [Cheshire et al., 2005]. Hence, the seasonal pattern of primary productivity in the Gulf may have changed from being predominantly in the winter, to having a greater summer component. Indeed productivity was relatively high during the LGM, as documented by high absolute abundances of cysts produced by heterotrophic taxa and moderate abundances of BioSi \% (Figures 2 and 4). Abundances of cysts produced by autotrophic taxa show large fluctuations, in particular O. centrocarpum, S. bentorii, and S. pachydermus (Figure 3), and are likely indicative of more dynamic climatic and oceanographic conditions during the LGM. Our interpretations are supported by geochemical data in McClymont et al. [2012], who also suggest that the NPH and ITCZ were more dynamic during the LGM, in addition to having a more southerly location.

[39] The transition from MIS 2 to MIS 1 is relatively abrupt with a sudden change in the dinoflagellate species assemblage. The species characteristic of MIS 2, O. centrocarpum and $S$. pachydermus, are now much more stable and reduced in abundance. The most important shift in assemblage is the 
consistent presence of the tropical species $T$. vancampoae, $S$. reidii, and $B$. spongium. This change in species composition, together with high dinoflagellate cyst diversity, indicates an increase in SST. In addition, two species that are known to increase in abundance in nutrient rich waters, Quinquecuspis concreta and Echinidinium aculeatum [e.g., Marret and Zonneveld; 2003; Radi et al., 2007; Pospelova et al., 2008; Verleye and Louwye, 2010] reach their maximum abundances in MIS 1. Thus the dinoflagellate cyst assemblage suggests this interval from 11 to $6.8 \mathrm{ka}$ saw higher SSTs and an increase in upwelling strength or frequency.

[40] Barron et al. [2004] propose a cool early MIS 1, as they document a relative decrease in the tropical diatom Azpeitia nodulifera and the alkenone record also shows a decrease in SST at $11 \mathrm{ka}$ [McClymont et al., 2012]. While the dinoflagellate cyst record suggests warm SSTs, this discrepancy can be explained by a higher seasonality during the early to mid Holocene. Upwelling increased in the early Holocene [this study; McClymont et al., 2012], likely occurring predominantly in the winter months and could explain the apparent drop in SST suggested by the diatom and alkenone records. While the increased solar insolation received during the summer months [e.g., Kutzbach and Liu, 1997] likely generated high temperatures at the sea-surface favouring the production of tropical dinoflagellate cysts.

\subsection{Millennial-Scale Variability}

\subsubsection{Dansgaard-Oeschger Events}

[41] During MIS 3 there are a number of millennial-scale climatic oscillations that were first documented in Greenland ice cores, termed Dansgaard-Oeschger events [Dansgaard et al., 1993], which are recorded worldwide [Voelker et al., 2002]. On the California margin, the bioturbation index and benthic foraminifera assemblage from ODP core 893 in Santa Barbara Basin (SBB) correlate well to the D-O events recorded in Greenland [e.g., Behl and Kennett, 1996; Cannariato et al., 1999].

[42] In Guaymas Basin neither the dinoflagellate cyst assemblages nor geochemical records of $\%$ TOC and $\%$ BioSi show considerable change during D-O events, with perhaps the exception of D-O event 8. This is contrary to nearby regions outside of the Gulf such as SBB, the California margin, Baja California, and NW Mexico where D-O events are characterized by anoxia and/or high productivity as indicated by TOC [e.g., Behl and Kennett, 1996; Hendy and Pedersen, 2005; Cartapanis et al., 2011; E. Arellano-Torres, Paleoceanography of the eastern tropical north Pacific on millennial timescales, 209 pp, University of Edinburgh, Edinburgh, UK, unpublished $\mathrm{PhD}$ thesis, 2010] and dinoflagellate cysts [Pospelova et al., 2006].

[43] The greatest change in the dinoflagellate assemblage coeval with a D-O event occurs during event 8 , where L. machaerophorum, Spiniferites taxa, and $N$. labyrinthus increase in abundance. In addition, low BioSi \% during this interval suggests there were fewer diatom blooms. An increase in autotrophic dinoflagellate cyst taxa and low \% BioSi may indicate a reduction in the supply of nutrients to the surface waters through reduced upwelling.

\subsubsection{Heinrich Events and the Younger Dryas}

[44] Of the four Heinrich events that occurred during our record, HE1 is the most pronounced in all of the proxies recorded thus far on this core, including the dinoflagellate cyst record. During HE1 there is a large increase in cyst concentrations of autotrophic taxa, while absolute abundances of heterotrophic taxa decline, indicating reduced upwelling (Figure 4). In addition the BioSi record shows a drastic drop (Figure 2). Therefore, we interpret that autotrophic dinoflagellates contributed more significantly to primary production during HE1. An increase in SST is also suggested due to high abundances of Spiniferites taxa. A rise in SST and a reduction in upwelling are supported by an increase in the temperature proxy $\mathrm{U}_{37}^{\mathrm{K}}{ }^{\prime}$ and a decrease in BioSi $\%, \delta^{30} \mathrm{Si}$, Si:N and Si:C recorded in our core [McClymont et al., 2012; Pichevin et al., 2012]. Other locations in the NE tropical Pacific also show evidence of decreased BioSi \% during Heinrich events [Arellano-Torres et al., 2011], suggesting the decrease in upwelling and productivity was regional in scale.

[45] Southwestern U.S. terrestrial records document an increase in precipitation during HE1 [Holmgren et al., 2006; Asmerom et al., 2010]. Terrigenous input proxies BIT index, $\mathrm{Al}$ and $\mathrm{Ti}$, also increase in Guaymas Basin sediments during HE1 [Barron et al., 2004; Cheshire et al., 2005; Dean, 2006; McClymont et al., 2012] and could be caused by increased fluvial or eolian input via summer convective storms. Together an increase in precipitation, a decrease in upwelling, and warm SSTs are analogous to El Niño-like or summer-like conditions in the modern Gulf. In contrast, colder SST conditions are documented further north along the California margin [e.g., Hendy et al., 2004; Pak et al., 2012]. This suggests the signal in SW USA and NW Mexico during HE1 is more regional in nature and perhaps is related to the monsoonal climate, which is not present along the California margin.

[46] Other Heinrich events in Guaymas Basin are also characterized by low BioSi $\%, \delta^{30} \mathrm{Si}, \mathrm{Si}: \mathrm{N}$ ratio, and $\mathrm{Si}: \mathrm{C}_{\mathrm{org}}$ ratios [Pichevin et al., 2012]. There are however several other intervals in between Heinrich events where these proxies are also low [see Pichevin et al., 2012, their Figure5] suggesting that the particular set of climatic and oceanographic conditions that occurred during Heinrich events was not unique to these intervals. The dinoflagellate cyst records do not show any clear response to Heinrich events $2-4$, either by a change in the assemblage or a change in absolute abundance (Figures 3 and 4), again suggesting that these events were not characterized by a unique set of environmental conditions. Further support is provided by the sedimentary record which shows that while the Younger Dryas and all Heinrich events in the past $40 \mathrm{ka}$ were homogenous (Figure 2), several other intervals in between these events also did not have evident laminations.

[47] The Younger Dryas shows some similar characteristics to Heinrich events, where a drop in heterotrophic cyst concentrations and the $\mathrm{H} / \mathrm{A}$ ratio is evident, as well as a decline in BioSi $\%$ and $\delta^{30} \mathrm{Si}$ [Pichevin et al., 2012] reflecting reduced upwelling. Moderate abundances of the autotrophic taxa $O$. centrocarpum and Spiniferites taxa during this interval also support decreased upwelling and suggest warm SSTs. In the Gulf of California the YD has been interpreted as a time of transition [Sancetta, 1995]. Although the YD is generally known for its abrupt return to near-glacial conditions, in the Gulf of California neither dinoflagellate cyst assemblages (this study), diatom assemblages [Barron et al., 2004; Barron et al., 2005], nor SST proxies $\mathrm{U}_{37}^{\mathrm{K} \prime}$ and 
$\mathrm{TEX}_{86}^{\mathrm{H}}[$ McClymont et al., 2012] suggest there was a decrease in SST in Guaymas Basin during this period.

\section{Conclusions}

[48] The Gulf of California has a unique environmental setting with a monsoonal climate, seasonally shifting wind directions, high primary productivity, and the presence of the OMZ at intermediate depths. The interplay between these conditions can be related to continental-scale changes in the location of ITCZ and atmospheric pressure systems affecting regional circulation patterns and to more local influences such as upwelling. Dinoflagellate cysts were well preserved and abundant throughout MD02-2515 and show millennial-scale variability throughout MISs $1-3$, sometimes following global trends such as during D-O event 8, while other times following regional trends such as during the YD where warm SSTs are recorded.

- Three dinoflagellate cyst zones were defined and roughly correspond to boundaries between MISs 1 and 3. During MIS 1 and 3, cysts of heterotrophic taxa dominated, while MIS 2 saw a substantial increase in Operculodinium centrocarpum, an autotrophic species indicating unstable oceanographic conditions.

- Dinoflagellate cyst assemblages record D-O event 8, which is characterized by an increase in Spiniferites taxa and suggest warmer SSTs, and support a northern migration of the ITCZ.

- The LGM was very dynamic with many large fluctuations in cyst assemblages and abundances. Reduced winter upwelling and increased summer upwelling, with overall relatively high primary productivity is suggested. This interval saw a southward displacement of the ITCZ, cooler temperatures, and increased winter precipitation.

- The HE1 and the YD are characterized by a decrease in BioSi $\%$ and an increased abundance of autotrophic dinoflagellate cyst taxa. These events are suggested to have experienced a decrease in upwelling and relatively warm SSTs.

- The early Holocene was characterized by high species diversity of dinoflagellate cysts. The presence of the subtropical/tropical taxa Tuberculodinium vancampoae, Stelladinium reidii, and Bitectatodinium spongium indicate the highest SSTs observed in the record. High abundances of Quinquecuspis concreta and Echinidinium aculeatum support increased winter winds and enhanced upwelling.

[49] The results presented here reinforce previous paleoceanographical reconstructions of Guaymas Basin and provide additional insights into the past $40 \mathrm{ka}$ history of the basin. Variations in key indicator species show that the YD was characterized by warm SSTs and a reduction in upwelling, an observation equally true for diatoms [Barron et al., 2004; Barron et al., 2005]. Our biological proxies demonstrate that the Guaymas Basin area responds to both regional and broader, global-scale climatic variations, suggesting that this area may be particularly sensitive to future oceanographic shifts as climate change continues.

[50] Acknowledgments. Funding was provided by the Natural Science and Engineering Research Council of Canada (NSERC). We would like to thank Ruth Dwyer for sampling the core (University of Edinburgh), Ellen Roosen for providing the surface sediment sample analysed in this study
(Woods Hole Oceanographic Institute), Laetitia Pichevin (University of Edinburgh) and Erin McClymont (Durham University) for sharing previously published data, and Alice Chang for interesting discussions regarding geochemistry data from the core (University of British Columbia). Victoria Gray, Kirsten Kennedy, and Alanna Krepakevich are thanked for their laboratory assistance and Manuel Bringué for assistance with Figure 1 (University of Victoria). K.N.M. is a postdoctoral fellow of FWO (Belgium), who conducted this research at the University of Victoria (British Columbia, Canada). We are grateful to the Editor and anonymous reviewers for constructive feedback and insightful suggestions which greatly improved this manuscript.

\section{References}

Arellano-Torres, E., L. E. Pichevin, and R. S. Ganeshram (2011), Highresolution opal records from the the eastern tropical Pacific provide evidence for silicic acid leakage from HNLC regions during glacial periods, Ouat. Sci. Rev., 30, 1112-1121.

Asmerom, Y., V. J. Polyak, and S. J. Burns (2010), Variable winter moisture in the southwestern United States linked to rapid glacial climate shifts, Nat. Geosci., 3(2), 114-117.

Baba, J., C. D. Peterson, and H. J. Schrader (1991), Fine-grained terrigenous sediment supply and dispersal in the Gulf of California during the last Century, in The Gulf and Peninsular Province of the Californias, edited by J. Dauphin and B. Simoneit, pp. 589-602, American Association of the Petroleum Geology Memoires, Tulsa, Oklahoma.

Barron, J., D. Bukry, and J. Bischoff (2004), High resolution paleoceanography of the Guaymas Basin, Gulf of California, during the past 15000 years, Mar. Micropaleontol., 50(3-4), 185-207.

Barron, J., D. Bukry, and W. E. Dean (2005), Paleoceanographic history of the Guaymas Basin, Gulf of California, during the past 15,000 years based on diatoms, silicoflagellates, and biogenic sediments, Mar. Micropaleontol., 56(3-4), 81-102.

Bartlein, P. J., K. H. Anderson, P. M. Anderson, M. E. Edwards, C. J. Mock, R. S. Thompson, R. S. Webb, T., III Webb, and C. Whitlock (1998), Paleoclimate simulations for North America over the past 21,000 years: Features of the simulated climate and comparisons with paleoenviornmental data. Quat. Sci. Rev., 17, 549-585.

Baumgartner, T. R. (1987), High resolution paleoclimatology from the varved sediments of the Gulf of California, $287 \mathrm{pp}$, Oregon State University, Oregon, USA, PhD thesis.

Baumgartner, T. R., V. Ferreira-Bartrina, and P. Moreno-Hentz (1991), Varve formation in the central Gulf of California: a reconsideration of the origin of the dark laminae from the 20th century varve record, in The Gulf and Peninsular Province of the Californias, edited by J. Dauphin and B. Simoneit, pp. 617-635, American Association of Petroleum Geology Memoires, Tulsa, Oklahoma.

Beaufort, L., and Member of the Scientific Party (2002), Cruise Report: MD126 MONA (Marges Ouest Nord Américanes) IMAGES VIII, Institut Polaire Francais Paul-Émile Victor (IPEV), pp 1-453, France.

Behl, R. J., and J. P. Kennett (1996), Brief interstadial events in the Santa Barbara basin, NE Pacific, during the past $60 \mathrm{kyr}$, Nature, 379(6562), 243-246.

Betancourt, J. L. (1984), Late Quaternary plant zonation and climate in Southeastern Utah, The Great Basin Naturalist, 44(1), 1-35.

Bouimetarhan, I., F. Marret, L. Dupont, and K. A. F. Zonneveld (2009), Dinoflagellate cyst distribution in marine surface sediments off West Africa $\left(17-6^{\circ} \mathrm{N}\right)$ in relation to sea-surface conditions, freshwater input and seasonal coastal upwelling, Mar. Micropaleontol., 71(3-4), 113-130.

Bray, N. A. (1988a), Water mass formation in the Gulf of California, J .Geophys. Res.-Oceans, 93(C8), 9223-9240.

Bray, N. A. (1988b), Thermohaline circulation in the Gulf of California J. Geophys. Res.-Oceans, 93(C5), 4993-5020.

Broecker, W., G. Bond, M. Klas, E. Clark, and J. McManus (1992), Origin of the northern Atlantic's Heinrich events, Climate Dynamics, 6(3), 265-273.

Bujak, J. P. (1984), Dinoflagellate cysts and acritarchs from the Bering Sea and Nothern North Pacific, DSSP Leg 19. Micropaleon., 30(2), 180-212.

Byrne, R., P. Mudie, and A. Soutar (1990), A pollen/dinoflagellate chronology for DSDP site 480, Gulf of California, in Proceedings of the 6th annual PACLIM workshop, March 5-8, 1989, vol. 23, edited by J. L. Betancourt and A. M. MacKay, pp. 105-110, Interagency ecological studies program for the Sacramento-San Joaquin Estuary, Tuscon, Arizona.

Calvert, S. E. (1966), Origin of diatom-rich varved sediments from Gulf of California, J. Geol., 74(5P1), 546-565.

Cannariato, K. G., J. P. Kennett, and R. J. Behl (1999), Biotic response to late Quaternary rapid climate switches in Santa Barbara Basin: Ecological and evolutionary implications, Geology, 27(1), 63-66

Cartapanis, O., K. Tachikawa, and E. Bard (2011), Northeastern Pacific oxygen minimum zone variability over the past $70 \mathrm{kyr}$ : Impact of biological production and oceanic ventilation, Paleoceanography, 26, PA4208. 
Cheshire, H., J. Thurow, and A. J. Nederbragt (2005), Late Quaternary climate change record from two long sediment cores from Guaymas Basin, Gulf of California, J. Quat. Sci., 20(5), 457-469.

Clark, P. U., A. S. Dyke, J. D. Shakun, A. E. Carlson, J. Clark, B. Wohlfarth, J. X. Mitrovica, S. W. Hostetler, and A. M. McCabe (2009), The last glacial maximum, Science, 325(5941), 710-714.

Clement, A. C., and L. C. Peterson (2008), Mechanisms of abrupt climate change of the last glacial period, Rev. Geophys., 46(4), RG4002.

Dale, B. (1996), Dinoflagellate cyst ecology: Modeling and geological applications, in Palynology: Principles and Applications, edited by J. Jansonius, D. C. McGregor, pp. 1249-1275, AASP Foundation, Salt Lake city, UT.

Dale, B. (2009), Eutrophication signals in the sedimentary record of dinoflagellate cysts in coastal waters, J. Sea Res., 61(1-2), 103-113.

Dale, B., A. L. Dale, and J. H. F. Jansen (2002), Dinoflagellate cysts as environmental indicators in surface sediments from the Congo deepsea fan and adjacent regions, Palaeogeo., Palaeoclim., Paleoecol., 185, 309-338.

Dansgaard, W., et al. (1993), Evidence for general instability of past climate from a 250-kyr ice-core record, Nature, 364(6434), 218-220.

Dean, W. E. (2006), The geochemical record of the last 17,000 years in the Guaymas Basin, Gulf of California, Chem. Geol., 232(3-4), 87-98.

de Vernal, A., et al. (2001), Dinoflagellate cyst assemblages as tracers of sea-surface conditions in the northern North Atlantic, Arctic and subArctic seas: The new " $\mathrm{n}=677$ " data base and its application for quantitative palaeoceanographic reconstruction, J. Quat. Sci., 16(7), 681-698.

Douglas, R., O. Gonzalez-Yajimovich, J. Ledesma-Vazquez, and F. Staines-Urias (2007), Climate forcing, primary production and the distribution of Holocene biogenic sediments in the Gulf of California, Quat. Sci. Rev., 26(1-2), 115-129.

Gómez, F. (2005), A list of free-living dinoflagellate species in the world's oceans, Acta. Bot. Croat., 64(1), 129-212.

Grigg, L. D., Whitlock, C. and Dean, W. E. (2001), Evidence for millennialscale climate change during Marine Isotope Stages 2 and 3 at Little Lake, Western Oregon, U.S.A., Quat. Res., 56, 10-22.

Fletcher, W. J. and Sánchez Goñi, M. F. (2008), Orbital- and sub-orbitalscale climate impacts on vegetation of the western Mediterranean basin over the last 48,000 yr, Quat. Res., 70 (3), 451-464.

Hansen, P. J. (1991), Quantitative importance and trophic role of heterotrophic dinoflagellates in a coastal pelagial food web, Mar. Ecol. Prog. Ser., 73(2-3), 253-261.

Hendy, I. L., and J. P. Kennett (1999), Latest Quaternary North Pacific surface-water responses imply atmosphere-driven climate instability, Geology, 27, 291-294.

Hendy, I.1., T. F. Pedersen, J. P. Kennett, and R. Tada (2004). Intermittent existence of a southern Californian upwelling cell during submillennial climate change of the last $60 \mathrm{kyr}$, Paleoceanography, 19, PA3007.

Hendy, I. L., and T. F. Pedersen (2005), Is pore water oxygen content decoupled from productivity on the California Margin? Trace element results from Ocean Drilling Program Hole 1017E, San Lucia slope, California, Paleoceanography, 20(4).

Holmgren, C. A., J. L. Betancourt, and K. A. Rylander (2006), A 36,000-yr vegetation history from the Peloncillo Mountains, southeastern Arizona, USA, Palaeogeogr. Palaeoclimat. Palaeoecol., 240(3-4), 405-422.

Jacobson, D. M., and D. M. Anderson (1986), Thecate heterotrophic dinoflagellates-Feeding-behavior and mechanisms, J. Phycol., 22(3), $249-258$.

Jouzel, J., et al., (2007). Orbital and millennial antarctic climate variability over the past 800,000 years, Science, 317(5839), 793-796.

Keigwin, L., and G. Jones (1990), Deglacial climatic oscillations in the Gulf of California, Paleoceanography, 5(6), 1009-1023.

Kutzbach, J. E. (1988), Climatic changes of the last 18,000 yearsObservations and model simulations, Science, 241(4869), 1043-1052.

Kutzbach, J. E., and Z. Liu (1997), Response of the African monsoon to orbital forcing and ocean feedbacks in the middle Holocene, Science, $278,440-443$

Lentin, J. K., and G. L. Williams (1993), Fossil dinoflagellates: Index to genera and species, Am. Assoc. of Strat. Palynol. Found. Cont. Ser., 28, 864.

Lewis, J., J. D. Dodge, and A. J. Powell (1990), Quaternary dinoflagellate cysts from the upwelling system offshore Peru, hole 686B, ODP leg 112, Proceedings of the Ocean Drilling Program, Scientific Results, $112,323-328$

Limoges, A., J. F. Kielt, T. Radi, A. C. Ruiz-Fernandez, and A. de Vernal (2010), Dinoflagellate cyst distribution in surface sediments along the south-western Mexican coast $\left(14.76^{\circ} \mathrm{N}\right.$ to $\left.24.75^{\circ} \mathrm{N}\right)$, Mar. Micropaleontol., 76(3-4), 104-123.

Marret, F., and K. A. F. Zonneveld (2003), Atlas of modern organic-walled dinoflagellate cyst distribution, Rev. Palaeobot. Palyno., 125(1-2), 1200.
Martínez-Hernández, E., and H. E. Hernández-Campos (1991), Distribución de quistes de dinoflagelados y acritarcas en sedimentos Holocénicos del Golfo de California, Paleontologia Mexicana, 37, 1-133.

Matsuoka, K. (1999), Eutrophication process recorded in dinoflagellate cyst assemblages - A case of Yokohama Port, Tokyo Bay, Japan, Sci. Total Environ., 231(1), 17-35.

Matsuoka, K., L. B. Joyce, Y. Kotani, and Y. Matsuyama (2003), Modern dinoflagellate cysts in hypertrophic coastal waters of Tokyo Bay, Japan, J. Plankton Res., 25(12), 1461-1470.

McClymont, E. L., R. S. Ganeshram, L. E. Pichevin, H. Talbot, B. van Dongen, R. C. Thunell, A. M. Haywood, J. S. Singarayer, and P. J. Valdes (2012), Sea-surface temperature records of termination 1 in the Gulf of California: Challenges for seasonal and interannual analogues of tropical Pacific climate change, Paleoceanography, 27, PA2202.

Mertens, K. N., A. Yamaguchi, H. Kawami, S. Ribeiro, B. S. Leander, A. M. Price, V. Pospelova, M. Ellegaard, and K. Matsuoka (2012), Archaeperidinium saanichi sp. nov.:A new species based on morphological variation of cyst and theca within the Archaeperidinium minutum Jörgensen 1912 species complex, Mar. Micropaleontol., 96-97, 48-62.

Pak, D. K., D. W. Lea, and J. P. Kennett (2012), Millennial scale changes in sea surface temperature and ocean circultation in the northeast Pacific, 10-60 kyr BP, Paleoceanography, 27, PA1212.

Pares-Sierra, A., A. Mascarenhas, S. G. Marinone, and R. Castro (2003), Temporal and spatial variation of the surface winds in the Gulf of California, Geophys. Res. Lett., 30(6), 1312.

Peltier, W. R., and R. G. Fairbanks (2006), Global glacial ice volume and last glacial maximum duration from an extended Barbados sea level record, Quat. Sci. Rev., 25(23-24), 3322-3337.

Peterson, L. C., G. H. Haug, K. A. Hughen, and U. Röhl (2000), Rapid changes in the hydrologic cycle of the tropical Atlantic during the last glacial, Science, 290(5498), 1947-1951.

Pichevin, L. E., R. S. Ganeshram, B. Reynolds, F. G. Prahl, T. F. Pedersen, R. C. Thunell, and E. L. McClymont (2012), Silicic acid biogeochemistry in the Gulf of California: Insights from sedimentary $\mathrm{Si}$ isotopes, Paleoceanography, 27, PA2201.

Pospelova, V., G. L. Chmura, W. S. Boothman, and J. S. Latimer (2002), Dinoflagellate cyst records and human disturbance in two neighboring estuaries, New Bedford Harbor and Apponagansett Bay, Massachusetts (USA), Sci. Total Environ., 298(1-3), 81-102.

Pospelova, V., T. F. Pedersen, and A. de Vernal (2006), Dinoflagellate cysts as indicators of climatic and oceanographic changes during the past 40 kyr in the Santa Barbara Basin, southern California, Paleoceanography, 21(2), PA2010.

Pospelova, V., A. de Vernal, and T. F. Pedersen (2008), Distribution of dinoflagellate cysts in surface sediments from the northeastern Pacific Ocean $\left(43-25^{\circ} \mathrm{N}\right)$ in relation to sea-surface temperature, salinity, productivity and coastal upwelling, Mar. Micropaleontol., 68(1-2), 21-48.

Prauss, M. L. (2002), Recent global warming its influence on marine palynology within the central Santa Barbara Basin, offshore southern California, U.S.A., Palynology, 26, 217-238

Price, A. M., and V. Pospelova (2011), High-resolution sediment trap study of organic-walled dinoflagellate cyst production and biogenic silica flux in Saanich Inlet (BC, Canada), Mar. Micropaleontol., $80(1-2), 18-43$.

Pride, C., R. Thunell, D. Sigman, L. Keigwin, M. Altabet, and E. Tappa (1999), Nitrogen isotopic variations in the Gulf of California since the last deglaciation: Response to global climate change, Paleoceanography, 14 (3), 397-409.

Radi, T., and A. de Vernal (2004), Dinocyst distribution in surface sediments from the northeastern Pacific margin $\left(40-60^{\circ} \mathrm{N}\right)$ in relation to hydrographic conditions, productivity and upwelling, Rev. Palaeobot. Palyno., 128(1-2), 169-193.

Radi, T., V. Pospelova, A. de Vernal, and J. V. Barrie (2007), Dinoflagellate cysts as indicators of water quality and productivity in British Columbia estuarine environments, Mar. Micropaleontol., 62(4), 269-297.

Rochon, A., A. de Vernal, J.-L. Turon, J. Matthiessen, and M. J. Head (1999), Distribution of recent dinoflagellate cysts in surface sediments from the North Atlantic Ocean and adjacent seas in relation to sea-surface parameters, Am. Assoc. of Stratigr. Palynol. Found. Cont. Ser., 1-146.

Roden, G. I. (1958), Oceanographic and meteorological aspects of the Gulf of California, Pac. Sci., 12(1), 21-45.

Sancetta, C. (1995), Diatoms in the Gulf of California-Seasonal flux patterns and the sediment record for the last 15,000 years, Paleoceanography, 10(1), 67-84.

Siddall, M., E. J. Rohling, A. Almogi-Labin, C. Hemleben, D. Meischner, I. Schmelzer, and D. A. Smeed (2003), Sea-level fluctuations during the last glacial cycle, Nature, 423(6942), 853-858.

Smith, G. I. and F. A. Street-Perrott (1983), Pluvial lakes of western United States, in The Late Pleistocene, edited by S. C. Porter, pp 190-214, University Minnesota Press, Minneapolis. 
PRICE ET AL.: DINOFLAGELLATE CYSTS FROM GUAYMAS BASIN

Spaulding, W. G. (1991), Pluvial climatic episodes in North-America and North-Africa-Types and correlation with global climate, Palaeogeogr. Palaeoclimat. Palaeoecol., 84(1-4), 217-227.

Stuiver, M. and P. M. Grootes (2000), GISP2 oxygen istope ratios, Quat. Res., 53, 277-284.

ter Braak, C. J. F., and P. Smilauer (2002), CANOCO reference manual and CanoDraw for Windows user's guide. Software for Canonical Community Ordination (version 4.5), Microcomputer Power, Ithaca, New York.

Thunell, R. C. (1998), Seasonal and annual variability in particle fluxes in the Gulf of California: A response to climate forcing, Deep-Sea Res. Pt. I, 45(12), 2059-2083.

Thunell, R. C., C. J. Pride, E. Tappa, and F. Muller-Karger (1993), Varve formation in the Gulf-of-California-Insights from time-series sediment trap sampling and remote-sensing, Quat. Sci. Rev., 12(6), 451-\&.

Thunell, R. C., C. J. Pride, E. Tappa, and F. Muller-Karger (1994), Biogenic silica fluxes and accumulation rates in the Gulf of California, Geology, 22(4), 303-306.

Thunell, R. C., C. J. Pride, P. Ziveri, F. MullerKarger, C. Sancetta, and D. Murray (1996), Plankton response to physical forcing in the Gulf of California, J. Plankton Res., 18(11), 2017-2026.

Van Devender, T. R., R. S. Thompson, and J. L. Betancourt (1987), Vegetation history of the deserts of southwestern North America: The nature and timing of the late Wisconsin-Holocene transition, in North America and Adajent Oceans During the Last Deglaciation, edited by Ruddiman, W. H., and H. E. Wright, pp 323-352, Geological Society of America, Boulder, CO.

Verleye, T. J., and S. Louwye (2010), Recent geographical distribution of organic-walled dinoflagellate cysts in the southeast Pacific $\left(25-53^{\circ} \mathrm{S}\right)$ and their relation to the prevailing hydrographical conditions, Palaeogr. Palaeoclim., Palaeoecol., 298(3-4), 319-340.

Voelker, A. H. L., and workshop participants (2002) Global distribution of centennial-scale records of Marine Isotope Stage (MIS) 3: A database, Quat. Sci. Rev., 21, 1185-1212.

Wagner, J. D. M., J. E. Cole, J. W. Beck, P. J. Patchett, G. M. Henderson, and H. R. Barnett (2010), Moisture variability in the southwestern United States linked to abrupt glacial climate change, Nat. Geosci., 3 (2), 110-113.

Zeitzschel, B. (1969), Primary productivity in Gulf of California, Mar. Biol., 3 (3), 201-207.

Zonneveld, K. A. F. (1997), New species of organic walled dinoflagellate cysts from modern sediments of the Arabian Sea (Indian Ocean), Rev. Palaeobot. Palynol., 97(3-4), 319-337.

Zonneveld, K. A. F., and G. J. A. Brummer (2000), (Palaeo-)ecological significance, transport and preservation of organic-walled dinoflagellate cysts in the Somali Basin, NW Arabian Sea, Deep-Sea Res. Pt. II, 47 (9-11), 2229-2256.

Zonneveld, K. A. F., and T. Jurkschat (1999), Bitectatodinium spongium (Zonneveld, 1997) Zonneveld et Jurkschat, comb. nov. from modem sediments and sediment trap samples of the Arabian Sea (northwestern Indian Ocean): Taxonomy and ecological affinity, Rev. Palaeobot Palyno., 106(3-4), 153-169.

Zonneveld, K. A. F., et al. (2010), Selective preservation of organic matter in marine environments; processes and impact on the sedimentary record, Biogeosc., 7, 483-511. 